KEMAS 10 (2) (2015) 110-121
Jurnal Kesehatan Masyarakat

\title{
PEMETAAN STATUS GIZI BALITA DALAM MENDUKUNG KEBERHASILAN PENCAPAIAN MILLENIUM DEVELOPMENT GOALS (MDGs)
}

\author{
Maryani Setyowati ${ }^{\bowtie}$, Retno Astuti \\ Prodi DIII RMIK Fakultas Kesehatan Udinus Semarang
}

\section{Info Artikel}

Sejarah Artikel:

Diterima 8 Oktober 2014

Disetujui 26 November 2014

Dipublikasikan Januari 2015

Keywords:

Map;

Coverage Toddler Nutri-

tional Status;

MDGs;

\begin{abstract}
Abstrak
Permasalahan gizi masih ditemukan di wilayah Kota Semarang, terutama masalah gizi kurang dan gizi buruk bagi balita, hal ini terkait dengan pengelolaan data yang ada di Program gizi Dinas Kesehatan Kota Semarang. Status gizi balita juga memiliki peranan penting dalam mendukung pencapaian Millenium Development Goals (MDG’s) di Indonesia khususnya untuk indikator yaitu menurunkan tingkat kematian balita . Penelitian ini bertujuan untuk menghasilkan pemetaan cakupan status gizi balita di wilayah Kota Semarang guna mendukung pemantauan status gizi balita pada Program Perbaikan Gizi Masyarakat di Dinas Kesehatan Kota Semarang tahun 2014.Penelitian ini menggunakan bentuk deskriptif kuantitatif dengan pendekataan cross-sectional, serta metode yang digunakan untuk pengembangan sistem informasi yaitu SDLC atau System Development Life Cycle yang menggunakan program aplikasi PHP dengan basis data MySQ1 dan tampilan peta menggunakan Google Map, yang dapat diakses dengan menggunakan jaringan komunikasi data yaitu internet. Simpulan dari penelitian ini adalah adanya pemetaan dari status gizi balita yang terdapat di wilayah Kota Semarang berbasis web dan menggunakan google map yang mudah digunakan dan dapat memantau pencapaian untuk Program Perbaikan Gizi Masyarakat.
\end{abstract}

\section{MAPPING THE NUTRITIONAL STATUS OF CHILDREN IN SUPPORT OF SUCCESS ACHIEVEMENT OF MILLENNIUM DEVELOPMENT GOALS (MDGs)}

\begin{abstract}
Nutritional problems are still found in the region of the city, especially the problem of malnutrition and poor nutrition for infants, it is associated with the management of existing data on nutrition program Semarang City Health Office. Nutritional status of children also have an important role in supporting the achievement of the Millennium Development Goals (MDG's) in Indonesia, especially for indicators of lower levels of mortality. This research aims to generate mapping coverage nutritional status of children in the city of Semarang in order to support the monitoring of nutritional status of children in Community Nutrition Improvement Program in Semarang City Health Office in 2014. This study used quantitative descriptive form with pendekataan cross-sectional, as well as the methods used to development of information systems that SDLC or system Development Life Cycle. which uses PHP application program with MySQL database and display the map using Google Map, which can be accessed using a data communications network that is the internet. The conclusions of this study is the mapping of the nutritional status of children who are in the city of Semarang web based and uses google map are easy to use and can monitor the achievement of the Society for Nutrition Improvement Program
\end{abstract}

(C) 2015 Universitas Negeri Semarang 


\section{Pendahuluan}

Adanya pencapaian MDGs untuk menanggulangi kemiskinan dan kelaparan menjadikansuatu tantanganyangharusdihadapi di Indonesia, hal ini sesuai dengan penelitian yang menyebutkan bahwa tantangan utama pencapaian MDGs bidang kesehatan adalah bagaimana pemerintah dapat menerjemahkan komitmen dan kebijakan intervensi efektif yang sudah tersedia menjadi program rutin pelayanan kesehatan yang dapat langsung menyentuh masyarakat, terutama mereka yang paling membutuhkan, yaitu masyarakat miskin (Utomo, 2011). Pencapaian MDG'sdi Kota Semarang dapat dilihat dari hasil pencapaian perbaikan gizi yang sudah bisa mencapai target Nasional dan Provinsi yaitu terlihat penurunan prevalensi gizi kurang dari 5.69\% tahun 2010 menjadi $4.89 \%$ tahun 2011 , adanya peningkatan prevalensi gizi buruk pada tahun 2010 sebanyak 1.01\% dan pada tahun 2011 menjadi 1.05\%. Berdasarkan hasil tersebut pihak pemerintah masih perlu meningkatkan upaya kesehatan yang berkesinambungan karena keadaan sosial ekonomi terutama pada penduduk miskin yang mendasari terjadinya kurang gizi yang masih menjadi ancaman.Berkaitan hal tersebut maka Dinas Kota Semarang melaksanakan Program Perbaikan Gizi Masyarakat khususnya Pemantauan Pertumbuhan Balita. Keberhasilan dari kegiatan pemantauan pertumbuhan balita di Kota Semarang, dapat diukur dari beberapa kegiatan, meliputi cakupan K/S yaitu indikator untuk menggambarkan persentase balita yang mempunyai Kartu Menuju Sehat (KMS) atau buku KIA didapatkan cakupan K/S pada tahun 2012 sebesar 98,96 \% lebih tinggi dari tahun 2011 sebesar 98,30\% dan tahun 2010 sebesar $98,40 \%$. Jika dilihat cakupan K/S di Puskesmas Kota Semarang tahun 2012 sebagian besar telah mencapai target Kota Semarang 100\% sebanyak 30 puskesmas (81\%) dan ada yang belum mencapai target $100 \%$ sebanyak 7 puskesmas (19\%), disebabkan karena sebagian besar KMS atau buku KIA hilang atau rusak, serta kurangnya pengetahuan masyarakat tentang manfaat KMS atau buku KIA. Hal ini akan menyulitkan pemantauan pertumbuhan pada balita sehingga akan menyebabkan keterlambatan intervensi yang berakibat terjadinya growth faltering yang akan berdampak pada masalah gizi atau malnutrition.

Pemantauan pertumbuhan dan perkembangan bayi dan balita terkait dengan status gizi balita dilakukan dengan penimbangan bayi dan balita di posyandu, kegiatan ini juga diintegrasikan dengan pelayanan kesehatan dasar lain seperti KIA, imunisasi, dan pemberantasan penyakit. Berdasarkan laporan tahunan Bidang Kesehatan Keluarga tahun 2012 menunjukkan cakupan balita yang ditimbang atau D/S memberikan gambaran tingkat partisipasi masyarakat di Kota Semarang menunjukkan adanya peningkatan dari tahun 2010 sampai 2012, yang menunjukkan semakin tingginya partisipasi masyarakat dalam penimbangan di posyandu maka semakin baik balita yang bisa terpantau pertumbuhannya, yang dapat digunakan sebagai deteksi dini pertumbuhan sehingga bila terjadi masalah dapat segera ditangani. Pencapaian D/S di Kota Semarang tahun 2012 sebesar 78,51\% yang telah mencapai target, namun bila dibandingkan dengan target Nasional pencapaian D/S masih dibawah target sebesar $80 \%$ dari beberapa Puskesmas, hal ini disebabkan oleh beberapa faktor antara lain masih ada sebagian balita yang ditimbang di sarana kesehatan selain posyandu belum terlaporkan, karena sebagian masyarakat belum mengetahui manfaat kegiatan di Posyandu, tempat posyandu yang masih kurang nyaman, sarana posyandu yang kurang, dan kurangnya dukungan dari tokoh masyarakat maupun lintas sektoral. Indikator yang juga digunakan untuk melihat cakupan program gizi yaitu balita yang naik berat badannya atau N/D dapat memberikan gambaran tentang keberhasilan program. Cakupan N/D di Kota Semarang menunjukkan adanya peningkatan dari tahun 2010 sampai tahun 2012, hal ini menggambarkan semakin baiknya pertumbuhan balita di Kota di Kota Semarang, karena balita yang sehat dapat dilihat dari kenaikan berat badan tiap bulannya, bila kenaikan berat badan terus menerus pada usia balita maka kemungkinan akan semakin baik status gizinya. Namun masih ada puskesmas yang belum mencapai target sebanyak 16 (43\%), hal ini disebabkan karena faktor sosial ekonomi sehingga mempengaruhi ketersediaan 
pangan tingkat rumah tangga, pengetahuan dan kemampuan ibu kurang dalam merawat anaknya, adanya infeksi dan hygiene sanitasi rumah yang kurang. Hal ini didukung dengan penelitian tentang faktor langsung yang mempengaruhi status gizi balita yaitu tingkat konsumsi energi dan protein untuk balita dan merupakan salah satu faktor risiko underweight pada balita (Rahim, 2014).

Kegiatan pemantauan untuk perbaikan gizi masyarakat dilaksanakan berdasarkan hasil pencatatan dan pelaporan dari Program Perbaikan Gizi Masyarakat yang tercemin dari hasil penimbangan bayi dan balita setiap bulan yang dilakukan di posyandu dapat dilihat pada laporan puskesmas tahun 2012 di Kota Semarang yang menunjukkan jumlah Bayi Lahir Hidup sebesar 27.448 bayi dan jumlah balita yang ada (S) sebesar 110.694 balita, namun masih saja ditemukannya kasus bayi dengan Berat Badan Lahir Rendah (BBLR) pada tahun 2012 sebanyak 165 bayi $(0,6 \%)$ yang terdiri dari 71 bayi laki-laki dan 94 bayi perempuan. Hal ini menjadi dasar untuk kegiatan pemantauan gizi balita terus dilaksanakan (Dinas Kesehatan Kota Semarang, 2012).

Saat ini permasalahan gizi masih ditemukan di Kota Semarang dan jumlahnya yang cenderung bertambah yaitu masalah gizi kurang pada tahun 2012 sebanyak 1.091 balita dan masalah gizi buruk sebanyak 39 balita. Hal ini sangat disebabkan karena pola makan balita yang salah, faktor sosial ekonomi keluarga sehingga mempengaruhi terhadap kemampuan membeli pangan keluarga khususnya balita, adanya penyakit infeksi, hygiene sanitasi yang kurang, kemampuan ibu dan dukungan keluarga yang kurang dalam merawat balita baik dalam pemberian makanan maupun kesadaran untuk memantau pertumbuhan sehingga adanya keterlambatan penanganan pada saat awal balita mengalami gangguan pertubuhan. Sedangkan kasus gizi buruk mengalami peningkatan sebesar $1,21 \%$ dari tahun 2011 yang berjumlah 26 kasus, padahal dari seluruh kasus gizi buruk tersebut juga telah dilakukan intervensi khususnya upaya perbaikan gizi masyarakat dalam bentuk kegiatan pemberian makanan tambahan pemulihan selama 180 hari, perawatan serta pengobatan baik di puskesmas maupun rumah sakit dengan bantuan dana Program Asuransi Kesehatan Masyarakat Miskin (Askeskin) atau JAMKESMAS dan APBD II (Dinas Kesehatan Kota Semarang, 2012). Masalah gizi balita juga menjadi perhatian dari beberapa peneliti, salah satunya penelitian yang menunjukkan hasil bahwa untuk mengatasi masalah gizi pada anak usia di bawah lima tahundibutuhkan kebijakan yang terfokus memulihkan pertumbuhan dan statuskesehatan anak usia di bawah lima tahun dengan korelasi antara programgizi dan program lain, seperti kesehatan lingkungan dan imunisasi. Selainitu, pemerintah harus mengatur peranan posyandu sebagai fasilitas yangmembantu pemerintah untuk meningkatkan status kesehatan masyarakat (Sartika, 2012).

Laporan merupakan bentuk dari informasiyangdapatdisajikanuntukmasyarakat umum, sehingga untuk menghasilkan informasi yang berkualitas memerlukan suatu sistem informasi yang baik, termasuk Dinas Kesehatan Kota Semarang.Berdasarkan Keputusan Menteri Kesehatan RI Nomor. 192/MENKES/ SK/VI/2012 tentang Roadmap Rencana Aksi Penguatan Sistem Informasi Kesehatan Indonesia yang mempunyai tujuan agar terselenggaranya Sistem Informasi Kesehatan yang terintegrasi dengan memanfaatkan teknologi informasi dan komunikasi oleh seluruh pemangku kepentingan baik di tingkat Pusat dan Daerah sehingga proses kerja menjadi lebih efisien dan transparan sehingga mampu menciptakan informasi yang handal dalam mendukung pembangunan kesehatan, hal ini yang memacu Dinas Kesehatan Kota Semarang mengembangan sistem informasi kesehatan termasuk dalam dengan mengacu pada Sistem Kesehatan Nasional dan kebijakan-kebijakan pemerintah daerah dan pusat, dan juga dilaksanakan oleh Program perbaikan gizi pada bidang Kesehatan Keluarga Kota Semarang dengan menghasilkan laporan tahunan kegiatan bidang Kesehatan Keluarga Dinas Kesehatan Kota Semarang. Namun dalam pelaporan tersebut belum dapat menampilkan wilayah kerja Dinas Kesehatan Kota Semarang khususnya untuk melihat adanya permasalahan gizi masyarakat Kota Semarang sehingga dapat mengakibatkan kesulitan bagi pihak Dinas Kesehatan Kota 
Semarang untuk melakukan pemantauan secara dini terhadap status gizi balita untuk pencegahan kasus gizi kurang maupun buruk di masyarakat. Pengembangan sistem informasi gizi balita di Dinas Kesehatan Kota Semarang tidak terlepas dari kebijakan pemerintah, dengan memperhatikan prinsip-prinsip yaitu : pemanfaatan Teknologi Informasi dan Komunikasi (TIK), Keamanan dan kerahasiaan data, standarisasi, integrasi, kemudahan akses, keterwakilan, etika, integritas, dan kualitas suatu sistem informasi.Hal ini sesuai dengan penelitian yang menunjukkan bahwa Sistem Informasi Geografis (SIG) dapat digunakan berbagai penelitian untuk meningkatkan kesehatan masyarakat berdasarkan wilayah (Shaw, 2012). Tujuan dari penelitian ini yaitu menghasilkan pemetaan status gizi balita di wilayah Kota Semarang untuk mendukung pemantauan status gizi balita pada Program Perbaikan Gizi Masyarakat di Dinas Kesehatan Kota Semarang.

\section{Metode}

Penelitian ini menggunakan rancangan Deskriptif Kuantitatif dengan pendekatan crosssectional, karena penelitian ini menyelidiki secara cermat sistem informasi pada program gizi yang ada di wilayah Kota Semarang dan mengelola data gizi balita. Penelitian ini mempunyai variabel meliputi :input, status gizi balita, proses, pemetaan berbasis web, informasi : cakupan status gizi balita, serta pencapaian MDGs. Populasi penelitian ini berupa data status gizi balita yang mempunyai kriteria status gizi kurang hingga status gizi buruk yang ada di wilayah Kota Semarang. Sedangkan sampel penelitian berupa total populasi, untuk pengambilan sampel dilakukan dengan teknik sampling menggunakan metode non-acak sampling yaitu Judgment sampling yaitu merupakan suatu bentuk pengambilan sampel dengan kriteria tertentu atau memakai pertimbangan.

Penelitian ini menggunakan model pengembangan sistem informasi yaitu SDLC (System Development Life Cycles) yang merupakan suatu siklus kehidupan dari pengembangan sistem yang kegiatan saling terkait dan berkesinambungan. Model SDLC ini terdiri dari beberapa tahapan, yaitu:(1) Investigasi sistem, yaitu suatu tahapan atau fase untuk mengidentifikasi masalah dan peluang dari suatu sistem informasi berdasarkan pertimbangan tujuan yang akan dicapai oleh organisasi tersebut. Kegiatan ini dilakukan untuk mengetahui permasalahan sistem informasi pada Program Gizi Dinas Kesehatan Kota Semarang yaitu belum adanya pemetaan status gizi balita. (2) Analisis sistem, yaitu suatu fase yang melibatkan studi dari sistem yang saat ini berlangsung dan proses kerjanya untuk diidentifikasi dengan analisis SWOT untuk peningkatan sistem informasi. (3) Perancangan sistem, merupakan fase pengembangan yang mendefinisikan bagaimana suatu sistem informasi dapat digunakan dan harus dapat menyelesaikan permasalahan yang ada. Perancangan yang dilakukan dengan menggunakan pemrogaman berbasis web dengan PHP.

Pengumpulan data dan informasi dilakukan dengan metode berikut ini wawancara mendalam atau Depth Interview. Wawancara dilakukan dengan user atau pemakai sistem informasi yaitu: Ka.Sie Gizi bidang Kesehatan keluarga Dinas Kesehatan Kota Semarang, petugas pelaksana program gizi, dan petugas gizi di puskesmas.

Metode Observasi, metode ini dilakukan dengan menggunakan pedoman observasi, untuk mengamati tentang komponenkomponen sistem informasi, berupa data, laporan, sarana prasarana, serta sumberdaya manusia yang tersedia di Program Gizi bidang Kesehatan Keluarga Dinas Kesehatan Kota Semarang.

Metode Penelusuran Data Online, dalam hal ini peneliti mencari jurnal atau artikel ilmiah tentang penelitian yang sejenis, serta bahan untuk referensi.

Penafsiran hasil penelitian berupa sistem informasi gizi Balita sudah terdapat peta yang menunjukkan wilayah yang mengalami permasalahan gizi balita, dan sebagai sistem peringatan dini untuk pencegahan status gizi balita kurang maupun buruk.Penarikan kesimpulan penelitian dengan terbentuknya sistem informasi gizi balita dalam bentuk peta per kecamatan di wilayah kerja Dinas Kesehatan Kota Semarang yang berkualitas 
dan memenuhi kebutuhan yaitu untuk alat pendukung kegiatan pemantauan status gizi balita untuk melihat pencapaian MDGs di wilayah Kota Semarang.

\section{Hasil dan Pembahasan}

Tahapan pengembangan sistem informasi (SDLC), kegiatan ini meliputi dari beberapa tahapan untuk menghasilkan suatu bentuk rancangan sistem informasi yang baru yang diterapkan di sie gizi Bidang Kesga Dinas Kesehatan Kota Semarang.Adapun kegiatan yang dilakukan sebagai berikut :

Studi pendahuluan (prelimary study), dilakukan untuk mengetahui adanya masalah, peluang, dan arahan dari pengguna sistem informasi di sie gizi. Penemuan masalah dengan melakukan wawancara dan observasi di sie gizi Bidang Kesga Dinas Kesehatan Kota Semarang, dari hasil wawancara ditemukan permasalahan dalam sistem informasi yaitu belum adanya aplikasi untuk pengelolaan data dan informasi khususnya dalam bentuk pemetaan. Wawancara juga dilakukan di bagian sistem informasi Bidang PKPKL DKK Semarang untuk mendapatkan informasi atau sebagai pendukung untuk permasalahan yang ada. Peluang untuk dibuatnya Pemetaan Cakupan Status gizi Balita berbasis wilayah di Kota Semarang seuai dengan kegiatan yang ada di sie Gizi bagian Kesga DKK Semarang yaitu pencapaian Program Perbaikan Gizi masyarakat dengan sasaran pada balita, yang didukung adanya sumber daya yang tersedia di sie Gizi bagian Kesga DKK Semarang berupa perangkat keras berupa komputer, perangkat lunak, dan petugas yang terlibat dalam kegiatan ini. Kegiatan ini juga didukung dengan adanya arahan atau instruksi dari pengguna sistem yaitu Ka.sie Gizi bagian Kesga dengan mendukung adanya pemetaan cakupan status gizi balita berdasarkan adanya laporan yang dibutuhkan oleh Sie Gizi bagian Kesga DKK Semarang.Berdasarkan identifikasi masalah sistem informasi yang ada di sie Gizi bagian Kesga DKK Semarang ditunjukan dalam bentuk gambaran Sistem Informasi gizi balita sie Gizi bidang Kesehatan Keluarga Dinas Kesehatan Kota Semarang saat ini belum memiliki aplikasi secara khusus untuk pengelolaan data dan laporan gizi dari puskesmas. Sistem Informasi yang berjalan saat ini belum dapat menunjukkan gambaran tentang status gizi balita dalam bentuk peta.

Analisis Sistem (system analysis), kegiatan ini meliputi :

Perencanaan proyek (project planning), kegiatan ini dilakukan dengan membuat persiapan dalam bentuk proposal dan membuat jadwal untuk tahapan yang dilakukan untuk pengembangan sistem, serta mendiskusikan dengan bagian pengelolaan data dan informasi Dinas Kesehatan Kota Semarang untuk menentukan jenis atau bentuk sistem informasi bagian gizi yang akan dibuat.

Penelitian sistem yang ada, didapatkan bahwa sistem informasi di bagian gizi Bidang Kesga sudah menggunakan sistem komputerisasi.

Mendefinisikan masalah, didapatkan bahwa masalah yang dijumpai di bagian gizi Bidang Kesehatan keluarga Dinas Kesehatan Kota Semarang yaitu belum adanya aplikasi pengolahan data gizi balita untuk memantau status gizi balita yang ada di wilayah Kota Semarang, karena pihak Dinas Kesehatan Kota Semarang menerima laporan dari puskesmas di wilayah kerjanya, dan menggunakan laporan tersebut untuk diolah menjadi laporan Program Gizi yang masih manual.

Analisis sistem, kegiatan ini meliputi : (1) Mempelajari dan menganalisis keberadaan sistem informasi gizi balita di bagian gizi Bidang Kesga Dinas Kesehatan Kota Semarang yang berjalan saat ini, didapatkan bahwa sistem informasi gizi memiliki input atau masukan berupa data Register kohort bayi, register kohort balita, rekap hasil operasi timbang $(\mathrm{TB} / \mathrm{U})$ balita, rekap hasil operasi timbang $(\mathrm{BB} / \mathrm{U})$ balita, rekap hasil timbang $(\mathrm{BB} / \mathrm{PB}$ atau $\mathrm{BB} / \mathrm{TB})$, rekap kinerja puskesmas. Untuk proses atau pengolahan data sudah menggunakan komputer tetapi belum ada aplikasi pengolahan data secara otomatis. Sedangkan output atau keluaran yang dihasilkan berupa laporan penjaringan balita kurang gizi, laporan pemberian PMT gizi balita gizi buruk, laporan pemberian PMT gizi kurang, laporan pemberian PMT ibu hamil KEK dari keluarga miskin, laporan balita BGM-gizi buruk dan gizi kurang, laporan inisiasi menyusui dini,laporan 
kinerja puskesmas Program perbaikan gizi masyarakat; (2) Analisis terhadap sistem informasi gizi balita yang akan dirancang, dengan membuat sistem informasi berbasis web dengan pemrograman PHP dan data base My SQL dan menghasilkan peta dengan google map; (3) Analisis perangkat keras (hardware) yang digunakan untuk penerapan sistem informasi gizi balita, yaitu perangkat keras yang ada di Bidang Kesehatan Keluarga Dinas Kesehatan Kota Semarang berupa komputer sebanyak 3 (tiga) buah, dan laptop sebanyak 6 (enam) buah.

Analisis Kebutuhan sistem, yaitu mengidentifikasi kebutuhan informasi yang diperlukan oleh Ka.sie.Gizi Bidang Kesehatan Keluarga, staff atau pelaksana Program Gizi, dan staff atau pengelola data dan informasi Bidang PKPKL Dinas Kesehatan Kota Semarang, yang didapatkan hasil bahwa laporan yang dibutuhkan sesuai laporan yang ada saat ini.

Analisis Keputusan, pada tahap ini terdapat beberapa solusi alternatif yang akan dipilih untuk memenuhi kebutuhan sistem yang baru, dengan tujuan yaitu mengidentifikasi kandidat solusi, menganalisis kandidat solusi, sesuai kelayakannya dan merekomendasikan sebagai kandidat sistem yang akan dikembangkan. Alternatif pemilihan solusi yang ada pada pemetaan cakupan status gizi balita berbasis wilayah di sie Gizi bagian Kesga DKK Semarang yaitu :(1) Pemilihan Model pengembangan Sistem Informasi yang baru berupa pemetaan, model yang dipilih dengan pendekatan yang dimulai dari Ka.sie Gizi bagian Kesga DKK Semarang untuk menganalisis kebutuhan informasi berdasarkan kebijakan sie Gizi bagian Kesga, dengan sasaran dan kebijakan berupa Program Perbaikan Gizi Masyarakat, selanjutnya turun ke tingkat bawah yaitu staf sie Gizi bagian Kesga DKK Semarang. Proses pendekatan ini dilakukan untuk menentukan model, output, input, basis data, dan prosedur operasi.(2) Pemilihan perangkat lunak pengembangan sistem yang baru : pada pengembangan sistem informasi program gizi balita dipilih alternatif untuk membuat aplikasi program berupa pemetaan cakupan status gizi balita berbasis wilayah, dengan pertimbangan bahwa aplikasi program tersebut belum ada di DKK Semarang, oleh karena itu alternatif tersebut dipilih sesuai kebutuhan pengguna sistem.(3) Pemilihan sistem operasi sistem informasi yang baru : sistem operasi untuk sistem informasi yang baru dengan menggunakan Windows, karena komputer yang ada di Sie Gizi bagian Kesga DKK Semarang sudah menggunakan sistem operasi Windows, dan bersifat user friendly.(4) Pemilihan User atau pengguna sistem informasi yang baru : alternatif pemilihan pengguna dalam sistem informasi berupa pemetaan ini adalah multi user, dengan jaringan komunikasi data yang memungkinkan adanya komunikasi data antara puskesmas dengan sie Gizi bagian Kesga DKK Semarang.(5) Pemilihan Tools sistem informasi yang baru : tools yang dipakai untuk membangun sistem informasi bentuk pemetaan adalah PHP dengan basis data menggunakan My SQL dan google map untuk tampilan petanya.

Sistem rancang bangun, kegiatan ini dilakukan dengan mempertimbangkan bentuk aplikasi yang akan dibuat dan pemrograman yang digunakan untuk sistem informasi gizi balita ini.

Desain atau perancangan sistem :Kegiatan ini meliputi perancangan Sistem Informasi Balita yang berbasis wilayah dengan menggunakan bantuan tools berupa Ms. Visio untuk menggambarkan bentuk context diagram (CD) dan Data Flow Diagram (DFD), serta Program PHP dan MySQL untuk desain input, desain output, serta basis data. Tahapan perancangan sistem informasi berupa Pemetaan Cakupan Status Gizi Balita dalam mendukung Pencapaian MDG's tahun 2015, dengan tahapan kegiatan berupa Perancangan Model Sistem, meliputi :

Tujuan dari perancangan model sistem ini adalah pengembangan sistem informasi status gizi balita dalam bentuk pemetaan yang memberikan kemudahan untuk penyajian informasi untuk mendukung keberhasilan pencapaian MDG's tahun 2015 bagi sie Gizi bagian Kesga DKK Semarang. Adapun sasaran yang akan dicapai dengan diterapkannya sistem informasi ini adalah :kemudahan dan kecepatan dalam pengelolaan data dan informasi gizi balita; keamanan dan keakuratan data terjamin; kemudahan dalam melakukan analisis untuk pengambilan keputusan; kemudahan dalam 


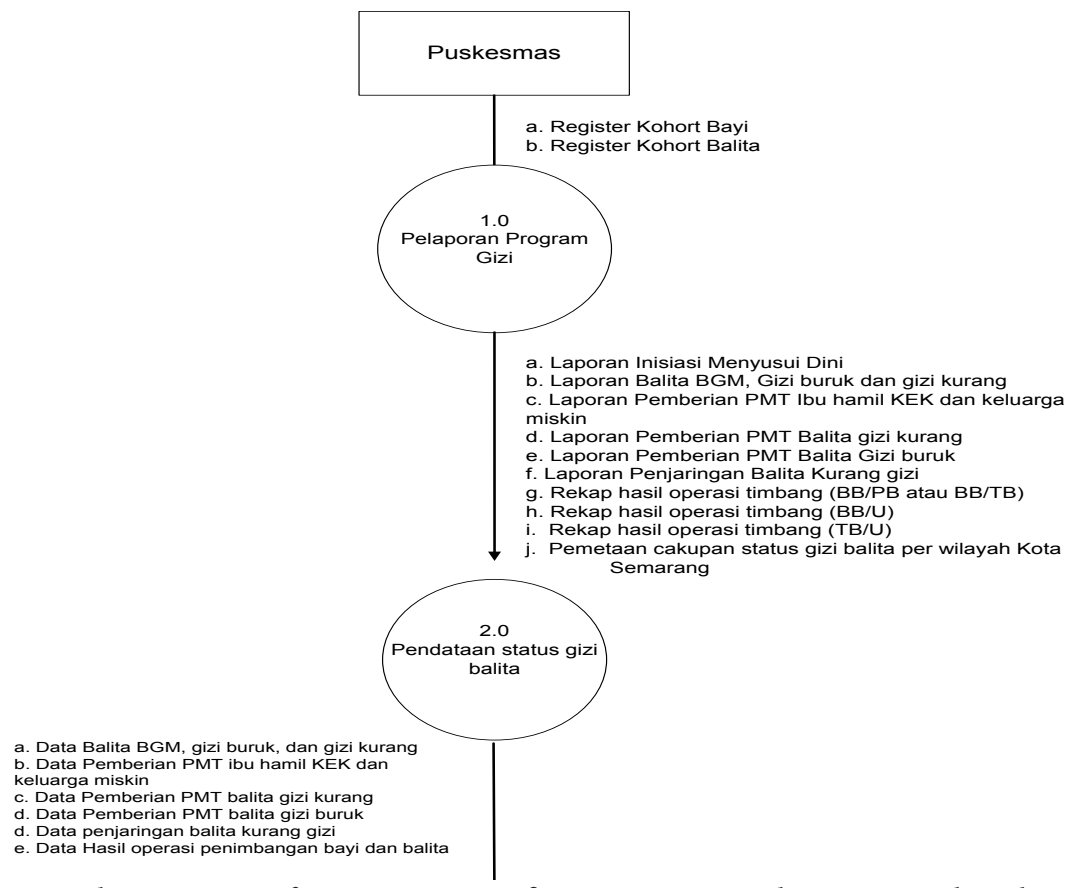

Gambar 1. DFD Level 1 Sistem Informasi Geografis Status Gizi Balita yang Dikembangkan Sumber : data primer

menampilkan cakupan status gizi balita berdasarkan wilayah; dan kebersamaan pemakaian dalam pengelolaan data gizi balita

Analisis Kebutuhan informasi dan Entitas yang terkait : berdasarkan hasil rancangan model peta untuk cakupan status gizi balita dalam bentuk diagram konteks, melalui diagram tersebut dapat dideskripsikan data dan informasi yang dibutuhkan dalam sistem informasi ini.

Diagram Alir Data Level 0 Sistem Informasi Geografis Status Gizi Balita

Setelah diagram konteks digambarkan maka selanjutnya diagram konteks tersebut diturunkan dalam bentuk yang lebih rinci dengan mendefinisikan seluruh proses yang ada dalam sistem informasi berikut ini :

Kegiatan berikutnya dilanjutkan dengan Perancangan Basis Data, adapun tahapan pembuatan proses perancangan basis data berikut ini :

Pendekatan Model Data E-R (Entity Relationship) : model data ini secara umum digambarkan dalam bentuk diagram E-R (Entity-Relationship Diagram $=$ ERD $)$. Relasirelasi yang ada dalam Sistem Informasi ini yaitu :

Relasi antara Balita dengan Puskesmas : Adanya relasi antara balita dengan puskesmas pada saat penimbangan. Banyak balita dapat menimbang ke satu puskesmas, dan satu puskesmas dapat melayani penimbangan banyak balita. Bentuk kardinalitasnya adalah many to one.

Relasi antara Puskesmas dengan Sie Gizi Bidang Kesga DKK Semarang :Relasi melaporkan yaitu relasi antara puskesmas dengan Sie Gizi bagian Kesga pada kegiatan

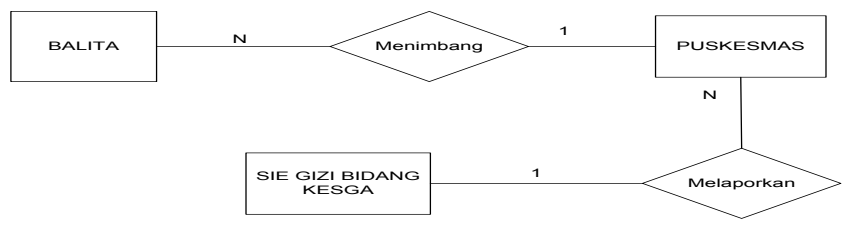

Gambar 2. Diagram ER akhir Sistem Informasi Geografis Status Gizi Balita Sumber : data primer 


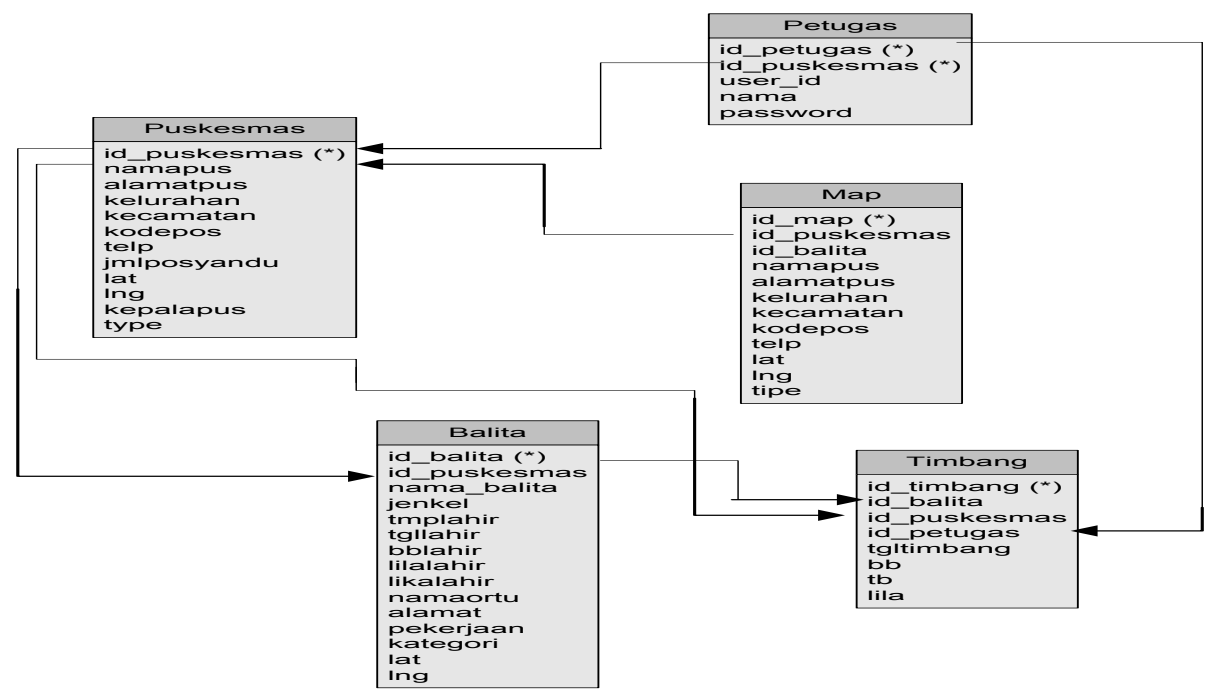

Gambar 3. Struktur File Basis Data

Sumber : data primer

pelaporan. Banyak Puskesmas melaporkan kegiatan program gizi ke satu Sie Gizi bagian Kesga DKK Semarang. Satu Sie Gizi bagian Kesga menerima laporan dari banyak puskesmas dalam wilayah kerjanya. Kardinalitasnya adalah many to one.

Rancangan ERD akhir : ERD akhir Sistem Informasi Geografis Status Gizi Balita merupakan gabungan dari beberapa relasi yang ada sebagai berikut :

Perancangan Struktur File Basis data : Perancangan struktur file basis data dibuat untuk menjelaskan field-field yang ada pada file data disertai tipe data, lebar, dan keterangan yang memperjelas. Adapun file-file data yang dapat diuraikan struktur basis datanya, berikut ini:

Pemetaan atau Sistem Informasi Status Gizi Balita berbasis wilayah di Kota Semarang dengan web menggunakan program aplikasi PHP dan basis data MySQL, serta bentuk pemetaan menggunakan Google Map sehingga perlu koneksi jaringan komunikasi data atau internet untuk aplikasinya. Untuk itu dilakukan

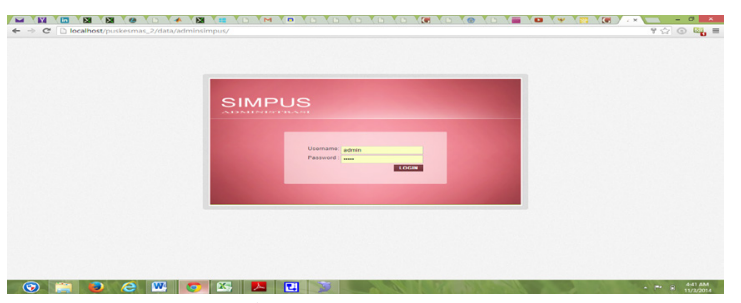

Gambar4.Tampilan Menu Login

Sumber : data primer perancangan tampilan Sistem Informasi Geografis Status Gizi Balita, meliputi :

Tampilan Awal Data Sistem Informasi Geografis Status Gizi Balita :Untuk pertama kali menampilkan data dalam bentuk web perlu masuk dalam alamat : localhost/puskesmas_2/ data/adminsimpus, dan muncul tampilan berikut :

Menu Login ini berfungsi untuk membuka menu berikutnya seperti menu input data sistem informasi.

Tampilan Menu Input Data terdapat beberapa pilihan dalam menu input ini yang digambarkan sebagai berikut :

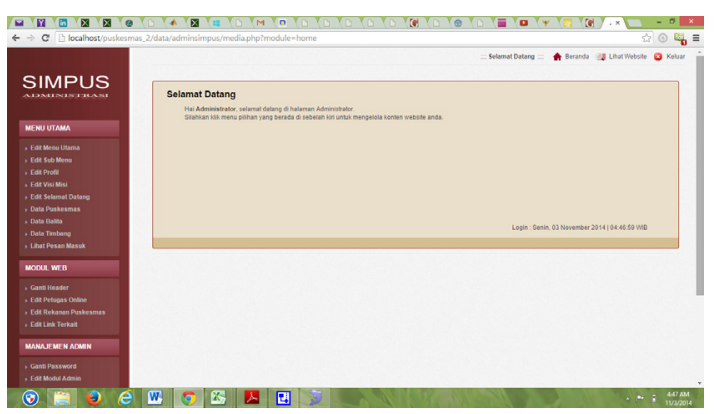

Gambar 5.Tampilan Menu Input Data

Sumber : data primer

Menu input data mempunyai pilihan untuk memasukan data, yaitu: Data Balita, Data Timbang, dan Data Puskesmas, dan beberapa pilihan untuk mengedit atau mengubah bentuk tampilan dalam gambar petanya.

Tampilan Peta Cakupan Status Gizi 


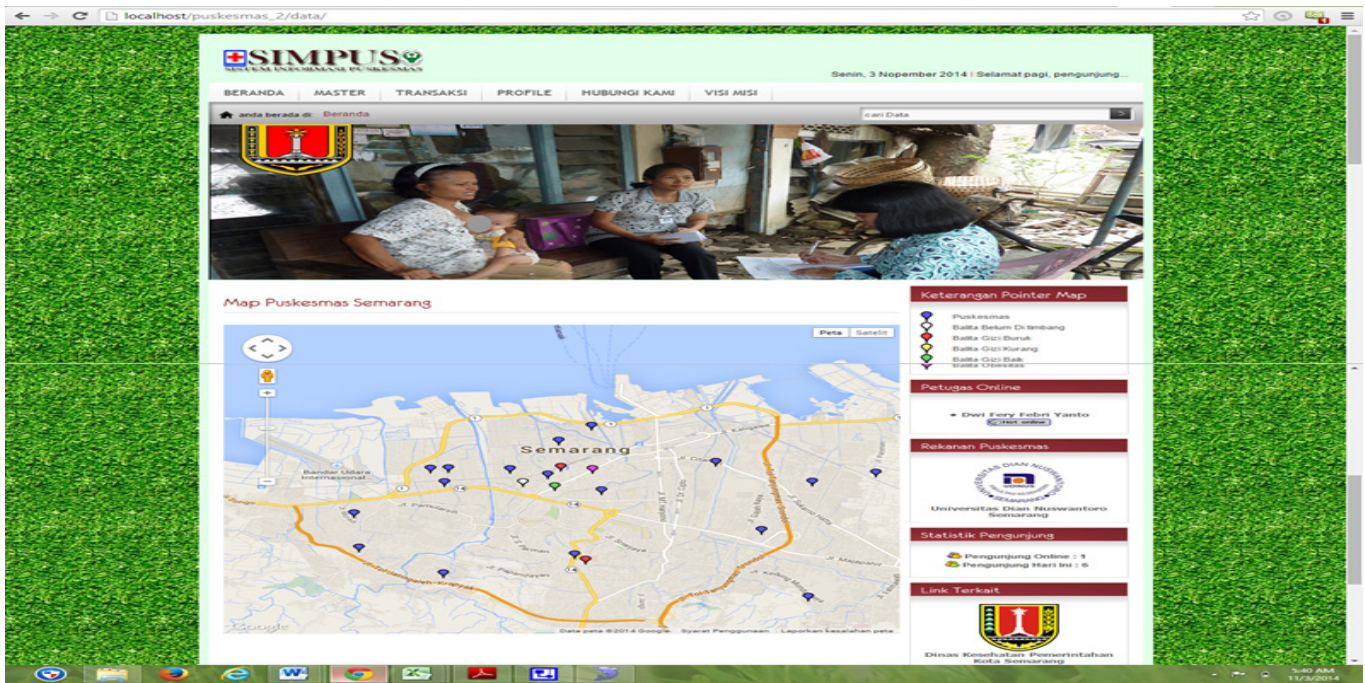

Gambar 6. Tampilan Peta Cakupan Status Gizi Balita di Kota Semarang

Sumber : data primer

Balita: Tampilan peta cakupan status gizi balita dapat dilihat dengan mengakses alamat : localhost/puskesmas_2/data.

Penelitian ini dilakukan untuk memetakan cakupan status gizi balita yang terdiri dari status gizi baik, status gizi kurang dan status gizi buruk berdasarkan wilayah kerja puskesmas di Kota Semarang berdasarkan standar Kategori dan ambang batas Status gizi anak berdasarkan indeksBerat badan menurut umur $(\mathrm{BB} / \mathrm{U})$ anak umur $0-60$ bulan. Keterbatasan penelitian ini yaitu hasil pemetaan cakupan status balita di wilayah Kota Semarang belum diukur dengan standar Kategori dan ambang batas status gizi anak berdasarkan indeks yang lainnya.Menurut buku Penilaian Status Gizi, didapatkan bhawa Status gizi dapat diartikan sebagai keadaan kesehatan individuindividu atau kelompok yang ditentukan oleh derajat kebutuhan fisik, energi dan zatzat gizi lain yang diperoleh dari pangan dan makanan yang dampak fisiknya diukur secara antropometri. Secara umum, status gizi dapat dikatakan sebagai fungsi kesenjangan gizi, yaitu selisih antara konsumsi zat gizi dengan kebutuhan zat gizi tersebut.Penilaian status gizi dapat menggunakan cara antropometri dimana Antropometri gizi berhubungan dengan berbagai pengukuran dimensi tubuh dan komposisi tubuh dari berbagai tingkat umur dan tingkat gizi. Antropometri sebagai indikator status gizi dilakukan dengan mengukur beberapa parameter. Parameter adalah ukuran tunggal dari tubuh manusia, antara lain: umur, berat badan (BB), tinggi badan (TB), lingkar lengan atas (LILA), lingkar kepala, lingkar dada, lingkar pinggul, dan lemak di bawah kulit. Parameter yang digunakan dalam penelitian ini adalah umur, BB, dan TB. Umur merupakan faktor penting dalam penentuan status gizi, karena kesalahan penentuan umur akan mengakibatkan kesalahan interprestasi status gizi. Hasil pengukuran $\mathrm{BB}$ dan TB yang akurat akan menjadi tidak berarti bila tidak disertai penentuan umur yang tepat. Penelitian yang sejenis telah dilakukan pada tahun 2013 dengan tentang Sistem Informasi Status Gizi balita dengan metode antropometri berbasis web yang menghasilkan grafik Fusion Chart di Dinas Kesehatan Kabupaten Sumba Barat.

Program Perbaikan Gizi Masyarakat yang dilaksanakan oleh Sie Gizi bidang Kesga DKK Semarang merupakan program rutin yang mempunyai jadwal maupun biaya yang telah dibuat perencanaannya, sehingga kegiatannya dapat dilakukan pemantauan, termasuk kegiatan untuk pembuatan peta cakupan Masyarakat kurang gizi, hal ini sesuai dengan pembuatan peta atau Sistem Informasi Geografis Status gizi Balita ini untuk mendukung kegiatan tersebut, salah satunya untuk mengetahui cakupan status gizi balita yang terdiri dari kategori Status gizi balita Baik, Kurang, dan Buruk. Program perbaikan gizi 
dilakukan sesuai dengan Peraturan Presiden Republik Indonesia nomor 42 tahun 2013 berisi tentang upaya bersama antara pemerintah dan masyarakat melalui penggalangan partisipasi dan kepedulian pemangku kepentingan secara terencana dan terkoordinasi untuk percepatan perbaikan gizi masyarakat prioritas pada seribu hari pertama, yang bertujuan percepatan perbaikan gizi masyarakat prioritas pada seribu hari pertama kehidupan dan meningkatkan komitmen pemangku kepentingan untuk memberikan perlindungan dan pemenuhan gizi masyarakat serta memperkuat implementasi konsep program gizi yang bersifat langsung dan tidak langsung. Salah satu sasaran dari program perbaikan gizi yaitu balita, yang merupakan kelompok rentan dari kasus kurang gizi, dan balita perlu adanya pertumbuhan dan perkembangan dalam kehidupannya, hal ini sesuai Program Gizi Anak yang dilakukan di Negara Amerika Serikat yaitu adanya perbaikan program gizi anak dengan membuat beberapa strategi untuk keamanan gizi anak di Negara tersebut (Kennedy, 2001).

Hasil penelitian ini menghasilkan pemetaan cakupan status gizi balita di wilayah Kota Semarang yang meliputi status gizi balita baik, status gizi balita kurang, dan status gizi balita buruk, dari data hasil penimbangan di puskesmas Kota Semarang, yang dapat digunakan untuk memantau status gizi balita sebagai salah satu kegiatan rutin yang dilakukan di Program Gizi Bidang Kesehatan Keluarga Dinas Kesehatan Kota Semarang yaitu untuk menjaring status gizi balita yang buruk dalam rangka mendukung pencapaian keberhasilan MDG's 2015 untuk menanggulangi kemiskinan dan kelaparan dan menurunkan angka kematian anak.Hal ini sejalan dengan penelitian tentangsistem informasi berbasis SIG (Sistem Informasi Geografis) sangat mendukung kegiatan dalam pemantauan status gizi dan dapat digunakan untuk menyusun kebijakan kesehatan dan perencanaan kesehatan status gizi terutama dalam hubungannya dengan pengalokasian sumber daya di tingkat kabupaten (Mutalazimah, 2009).

Adanya penetapan indikator MDGs tahun 2015 menjadikan Indonesia khususnya Dinas Kesehatan Kota Semarang yang bertanggung jawab dalam peningkatan kesehatan masyarakat dalam wilayah kerjanya perlu dukungan dari sumber daya termasuk untuk pengelolaan data dan informasi sehingga dibuatnya pemetaan cakupan status gizi balita dapat mendukung kinerja dari Program perbaikan gizi masyarakat.Berdasarkan laporan pencapaian tujuan Pembangunan Milenium atau MDGs di Indonesia pada tahun 2011, disebutkan yaitu sesuai Tujuan 1 : Menanggulangi Kemiskinan dan Kelaparan yang berupa Upaya penanggulangan kemisikinan di Indonesia menunjukkan kemajuan yang berarti dan ini sudah sesuai dengan target MDGs yang ditunjukkan dengan menurunnya proporsi penduduk yang hidup di bawah garis kemiskinan nasional dari 15,10\% (tahun 1990) menjadi 12,49\% (tahun 2011) dan indeks Kedalaman kemiskinan dari 2,70 menjadi 2,08 pada periode yang sama (Bappenas, 2012). Hal ini sejalan dengan penelitian tentang pencapaian MDG's tujuan ke 4 untuk meningkatkan kesehatan Ibu maternal dan anak di Democratic Republic of Congo (DRC) yang masih ditemukan masalah malnutrisi pada balita yang mempengaruhi pencapaian MDG's.(Ngianga, 2011 )

$$
\text { Pembuatanpeta cakupan dengan }
$$
menerapkan metode SDLC (System Development Life Cycle) yaitu suatu Siklus Hidup Pengembangan Sistem merupakan suatu bentuk yang digunakan untuk menggambarkan tahapan utama dan langkahlangkah di dalam tahapan tersebut dalam proses pengembangannya (Jogiyanto, 2005),mulai dari studi pendahuluan sampai dengan perancangan sistem informasi dengan dihasilkannya bentuk input data dan pemetaannya, hal yang sama juga dilakukan dengan penelitian yang menghasilkan media informasi pemanfaatan sistem informasi geografi untuk analisis spasial status gizi balita yang disajikan secara lebih menarik, lengkap dan dapat memberikan gambaran informasi mengenai peta status gizi balita. Pengembangan system dalam penelitian ini yaitu sistem informasi geografis yang dihasilkan dapat mendukung kegiatan dalam manajemen yaitu mendukung pemantauan status gizi balita dari Program Gizi Bidang Kesehatan Keluarga Dinas Kesehatan Kota Semarang, dan dalam pembuatan sistem informasi geografis juga memerlukan biaya atau 
modal yang cukup besar karena menggunakan teknologi informasi yaitu program berbasis web yang dihubungkan dengan google map, serta orang yang terlibat dalam pengembangan sistem ini juga merupakan orang yang terdidik hal ini sesuai dengan sumber daya manusia yang dimiliki oleh Program Gizi Bidang Kesehatan Keluarga Dinas Kesehatan Kota Semarang, yang mempunyai latar belakang pendidikan formal yaitu Sarjana Kesehatan Masyarakat, Diploma III Gizi dan SLTA, sehingga dari proses sampai penerapan sistem tidak ditemukan kendala dari pihak pengguna sistem.

Penelitian ini yang menghasilkan sistem informasi geografis yang bertujuan untuk dapat memudahkan untuk menginputkan data Balita, data timbang atau transaksi dan data puskesmas berbasis web dengan menggunakan program $P H P$ dan basis data $M y S Q L$, sehingga memudahkan bagi Sie Gizi bagian Kesga DKK Semarang dalam melakukan pemantauan Program Perbaikan Gizi Masyarakat khususnya untuk sasaran balita, yang termasuk kelompok rentan gizi, karena balita masih memerlukan gizi baik dalam masa pertumbuhan dan perkembangannya sehingga dapat dicegah adanya kasus gizi buruk yang merupakan salah satu masalah dalam kesehatan. Hal ini sejalan dengan penelitian tentang daerah positive deviance sebagai rekomendasi model perbaikan gizi, yaitu usaha perbaikan gizi jangka pendek dengan memberdayakan potensi masyarakat yang dimiliki terutama bidang sosial-budaya, meliputi aspek organisasi kemasyarakatan, pengetahuan dan bahasa, mata pencaharian, serta teknologi dan peralatan (Handayani, 2012).

Perancangan sistem merupakan tahapan yang dilakukan dalam penelitian ini, karena tujuan dari perancangan atau desain sistem yaitu untuk memenuhi kebutuhan kepada pemakai sistem dan untuk memberikan gambaran yang jelas dan rancang bangun yang lengkap kepada pemrogram komputer dan ahliahli teknik lainnya yang terlibat. (Jogiyanto, 2005). Hal ini juga dilakukan dalam penelitian ini, dengan membuat rancangan yang mudah dipahami dan digunakan oleh pihak terkait, meliputi rancangan tampilan awal, rancangan menu input serta rancangan pemetaan cakupan status gizi balita yang mudah dalam pengoperasiannya, serta sudah sesuai dengan rancang bangun yang harus disiapkan dengan memenuhi komponen-komponen sistem informasi meliputi menu input data balita, data puskesmas, data timbang, data wilayah. Untuk simpanan data atau database dengan menggunakan program $M y S Q L$. Prosedur yang diterapkan sesuai dengan kebijakan dari Dinas Kesehatan Kota Semarang untuk program gizi Bidang Kesehatan Keluarga, sedangkan informasi yang dihasilkan merupakan bentuk pemetaan cakupan status gizi balita dengan tampilan secara menarik dan bisa dilakukan update atau terbaruan data,dan orang-orang yang terlibat meliputi petugas puskesmas dan petugas program gizi Bidang Kesehatan Keluarga Dinas Kesehatan Kota Semarang. Sehingga dapat dinyatakan bahwa pemetaan cakupan status gizi balita sesuai dengan tujuan dari Program Gizi dalam mendukung pengolahan transaksi, pelaporan manajemen dan mendukung keputusan yang dilakukan oleh manajemen, termasuk tugas-tugas yang lainnya yang tidak dilakukan oleh komputer.Adanya penelitian yang mendukung bahwa pengembangan sistem informasi geografis diperlukan pengelolaan data wilayah yang akurat dan juga infrastruktur data kesehatan spasial secara interoperabilitas atau berbasis web yang dapat bermanfaat untuk mengatasi masalah malnutrisi.

Perbedaan sistem informasi gizi balita yang saat ini berjalan dengan yang dikembangkan yaitu sistem informasi status gizi yang dikembangkan sudah memiliki bentuk peta dalam penyajian informasinya sehingga dapat memudahkan bagi pihak Sie Gizi bagian Kesga untuk melakukan pemantauan cakupan status gizi balita di wilayah kerjanya yaitu Kota Semarang.Kebutuhan informasi penting untuk mendukung kegiatan manajemen dan sebagai dasar pengambilan keputusan oleh pihak manajer, sehingga diperlukan suatu informasi yang mempunyai kualitas, sebagai berikut : (a) Relevansi, yaitu berkaitan langsung dengan masalah yang ada. (b) Akurasi atau keakuratan, idealnya semua informasi harus akurat, tetapi peningkatan ketelitian sistem menambah biaya sehingga pihak manajer dapat menerima ketelitian yang kurang sempurna. Akurat berarti informasi harus bebas dari kesalahan-kesalahan dan tidak bias atau 
menyesatkan. (c) Ketepatan waktu, informasi harus bersedia untuk memecahkan masalah sebelum situasi krisis menjadi tidak terkendali atau kesempatan menghilang. Tepat waktu berarti informasi yang datang pada penerima tidak boleh terlambat, karena informasi yang sudah usang tidak mempunyai nilai lagi, karena informasi merupakan landasan di dalam pengambilan keputusan. (d) Kelengkapan, manajer harus mampu memperoleh informasi yang menyajikan gambaran lengkap dari suatu permasalahan atau penyelesaian. (e) Kemudahan untuk akses, agar informasi bisa diterima oleh pemakai dengan lancar dan mudah dalam pengolahan data.(f) Keringkasan, informasi harus ringkas agar sesuai dengan kebutuhan penerima informas. Hal ini sesuai yang dihasilkan dari penelitian ini yaitu penyajian informasi dalam bentuk pemetaan cakupan status gizi balita dengan memenuhi syarat untuk informasi yang berkualitas yaitu relevansi bahwa informasi yang dihasilkan berkaitan langsung dengan program perbaikan gizi di Dinas Kesehatan Kota Semarang; akurasi yaitu adanya ketelitian dari data yang akurat untuk pemetaan ini; ketepatan waktu yang dapat dihasilkan dari informasi yang dihasilkan karena dapat secara langsung melihat hasil dari pendataan status gizi balita dalam bentuk peta; kelengkapan informasi dapat disajikan dalam pemetaan cakupan status gizi balita selain dalam bentuk peta juga bisa menampilkan data balita yang sesuai dengan kriteria tersebut. Pemetaan cakupan status gizi balita mudah diakses oleh pihak yang berkaitan secara langsung seperti pihak Dinas Kesehatan Kota Semarang serta pihak puskesmas.Kebutuhan data dan informasi yang akurat dan lengkap dari tingkat puskesmas sangat dibutuhkan dalam pengembangan sistem ini selain dukungan dari pihak pengguna atau Program Gizi Bidang Kesehatan Keluarga Dinas Kesehatan Kota Semarang, sehingga dapat dikembangkan secara lebih lanjut untuk mencapai tujuan dari program perbaikan gizi.

\section{Penutup}

Sistem Informasi Status Gizi Balita di Sie Gizi Bidang Kesehatan Keluarga menggunakan sistem yang komputerisasi namun belum ada program aplikasi untuk pengelolaan data gizi terutama dalam bentuk peta sebagai bentuk penyajian lebih interaktif. Pemetaan berbasis web ini digunakan untuk melihat cakupan status gizi balita di wilayah kerja Dinas Kesehatan Kota Semarang dan sebagai pendukung pengambilan keputusan bagi pengelola program gizi bidang Kesga dan digunakan untuk melihat cakupan status gizi balita dalam mendukung tercapainya MGDs 2015.

\section{Daftar Pustaka}

Dinas Kesehatan Kota Semarang. 2012. Profil Kesehatan Kota Semarang. Semarang: Dinas Kesehatan Kota Semarang.

Handayani, O. W., \& Prameswari, G. N. 2012. Daerah Positive Deviance sebagai Rekomendasi Model Perbaikan Gizi. Jurnal Kemas, 7 (2) : 102-109.

Jogiyanto, H. 2005. Analisis dan Desain-Sistem Informasi : pendekatan terstruktur teori dan praktek aplikasi bisnis. Yogyakarta: ANDI.

Kennedy, E., \& Cooney, E. 2001. Development of the Child Nutrition Programs in th United States. The Journal of Nutrition, 431S-436S.

Mutalazimah, Handaga, B., \& Anggoro, A. 2009. Aplikasi Sistem Informasi Geografis pada Pemantauan Status Gizi Balita di Dinas Kesehatan Kabupaten Sukoharjo. Forum Geografi, 23 : 153 - 166.

Ngianga-Bakwin Kandala, T. P. 2011. Malnutrition among Children under the age five in the Democratic Republic of Congo (DRC) : does geographic location matter? BMC Public Heallth (11): 261-264.

Rahim, F. K. 2014. Faktor Risiko Underweight Balita Umur 7 - 59 Bulan. Kesehatan Masyarakat 9 (2) : 115-121.

Reynolds, R. S. 2008. Principles of Information System . Canada : Thomson Course Technology.

Sabrina Marx, R. P.-J. 2014. Geographic information analysis and web-based geoportas to explore malnutrition in sub-Saharan Africa : a systematic review of approaches. BMC Public Health , (14) : 1189.

Sartika, R. A. 2012. Analisis Pemanfaatan Program Pelayanan Kesehatan Status Gizi Balita. Jurnal Kesmas Universitas Indonesia.

Shaw, N. T. 2012. Geographical Information Systems and Health : Current State and Future Directions. Healthc Inform Research, 18 (2) : 88-96. 